Terra Nova

October 2018, Volume 30, Issue 5, Pages 380-388

http://dx.doi.org/10.1111/ter.12353

http://archimer.ifremer.fr/doc/00452/56344/

(c) 2018 John Wiley \& Sons Ltd

\title{
The offshore east african rift system: new insights from the sakalaves seamounts (Davie Ridge, SW Indian Ocean)
}

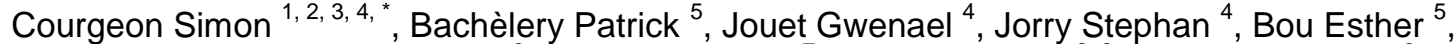 \\ Boudagher-Fadel Marcelle K. ${ }^{6}$, Révillon Sidonie ${ }^{7}$, Camoin Gilbert ${ }^{2,3}$, Poli Emmanuelle ${ }^{8}$
}

${ }^{1}$ University of Geneva; Department of Earth Sciences; Rue des Maraîchers 13 CH-1205 Geneva, Switzerland

${ }_{2}^{2}$ Aix Marseille Univ, CNRS; IRD, Coll, France

${ }^{3}$ CEREGE; Aix-en-Provence, France

${ }^{4}$ IFREMER, Unité Géosciences Marines; 29280 Plouzané ,France

${ }^{5}$ Université Clermont Auvergne, CNRS, IRD, OPGC, Laboratoire Magmas et Volcans; F-63000

Clermont-Ferrand, France

${ }_{7}^{6}$ University College London, Earth Science; 2 Taviton St London WC1H 0BT, UK

${ }^{7}$ SEDISOR/UMR 6538, Laboratoire Géosciences Océans, IUEM; 29280 Plouzané, France

${ }^{8}$ TOTAL Exploration and Production; CSTJF, Avenue Larribau 64000 Pau, France

*Corresponding author : Simon Courgeon, email address : simon.courgeon@gmail.com

\begin{abstract}
:
The offshore branch of the East African Rift System (EARS) has developed during late Cenozoic time along the eastern Africa continental margin. While Neogene-Pleistocene extensional tectonic deformation has been evidenced along the northern segment of the Davie Ridge, the spatial extent of deformation further south remains poorly documented. Based on recent and various oceanographic data sets (bathymetric surveys, dredge samples and seismic profiles), our study highlights active normal faulting, modern east-west extensional tectonic deformation and Late Cenozoic alkaline volcanism at the Sakalaves Seamounts $\left(18^{\circ} \mathrm{S}\right.$, Davie Ridge) that seem tightly linked to the offshore EARS development. In parallel, rift-related tectonic subsidence appears responsible for the drowning of the Sakalaves Miocene shallow-water carbonate platform. Our findings bring new insights regarding the development of the EARS offshore branch and support recent kinematic models proposing the existence of a plate boundary across the Mozambique Channel.
\end{abstract}




\section{Introduction and geological settings}

The Davie Ridge (DR, Fig. 1B) corresponds to a N170-trending bathymetric high, punctuated by successive seamounts, that crosses the Mozambique Channel from the East Africa margin $\left(\sim 9^{\circ} \mathrm{S}\right)$ to Madagascar $\left(\sim 23^{\circ} \mathrm{S}\right)$. It has been broadly accepted that the $\mathrm{DR}$, partly made of continental basement (Bassias, 1992), corresponds to the expression of a major transform margin resulting from the southward relative motion of Madagascar with respect to Africa between Middle Jurassic and Late Cretaceous time ( 175-80 Ma; e.g. Coffin and Rabinowitz, 1987; Klimke et al., 2018). In parallel, recent studies (Klimke and Franke, 2016; Sauter et al., 2018) have shown that the northern extremity of the DR (i.e. the Wulu Ridge and Kerimbas Graben eastern flank) is not genetically related to Mesozoic transform tectonic activity but instead results from Cretaceous volcanism and Neogene East African Rift System (EARS) activity. The presence of mafic alkaline volcanic rocks with a geochemical signature showing analogies with Cretaceous volcanic rocks from southeast Africa and Madagascar was also previously mentioned by Leclaire et al. (1989) and Bassias and Leclaire (1990) along the DR. Numerous studies concerning the Cenozoic evolution of the Mozambique Channel suggest that the DR is currently accommodating extensional tectonic activity related to the development of the offshore EARS (Fig. 1; Mougenot et al., 1986; Grimson and Chen, 1988; McGregor, 2015; Franke et al., 2015). Active plate deformation studies and kinematic models based on GPS and DORIS (Doppler Orbitography and Radiopositioning Integrated by Satellite) indicate the existence of one or more microplates between Madagascar and stable Africa (Nubia plate), including the Rovuma microplate between the Western rift and the DR (e.g., Chu and Gordon, 1999; Hartnady, 2002; Calais et al., 2006; Saria et al., 2014; Stamps et al., 2015; Fig. 1A). These results are supported

This article is protected by copyright. All rights reserved. 
by intense seismicity mostly associated with extensional earthquake source mechanisms (Fig. 1B, Dziewonski et al., 1981; Grimson and Chen, 1988; Ekström et al., 2012). The offshore branch of the EARS, first described by Mougenot et al. (1986), is marked by a transition from a mature rift basin offshore northern Mozambique (the Kerimbas Graben, Fig. 1B) to diffuse extension associated with juvenile faulting towards the Lacerda Graben and the DR (Franke et al., 2015). While the modern outline of the offshore EARS remains elusive southward, focused studies unraveling the geological evolution of the southern section of the DR throughout the Cenozoic and up to the present-day are lacking.

The Sakalaves seamounts extend over $200 \mathrm{~km}$, following the NNW-SSE DR trend between $17^{\circ} \mathrm{S}$ and $19^{\circ} \mathrm{S}$ latitudes (Fig. 1B \& $2 \mathrm{~A}$ ). This rough submarine relief is marked by an overall flat-top morphology of 275 sq.km (Fig. 2A,C), which corresponds to a drowned Oligocene-Miocene shallowwater carbonate platform whose flat top occurs around $400 \mathrm{~m}$ below sea level (Courgeon et al., 2016). The Sakalaves carbonate platform is characterized by volcanic morphologies (Fig. 2C) and by a dense network of normal faults that cut Miocene neritic carbonate sediments and that are tentatively interpreted as related to Late Cenozoic EARS development (Courgeon et al., 2016). Based on the analysis of dredge samples, seismic profiles and extensive bathymetry DEMs, this study aims to (1) investigate the modern structure and the Cenozoic evolution of the Sakalaves Seamounts and, (2) discuss their potential links with the development of the offshore EARS branch.

This article is protected by copyright. All rights reserved. 


\section{Data and Methods}

This study is based on geophysical and geological data acquired during the 2014 PTOLEMEE (Jorry, 2014) and PAMELA-MOZ1 (Olu, 2014) cruises (RV L'Atalante) and during the 2015 PAMELAMOZ4 (Jouet and Deville, 2015) cruise (RV Le Pourquoi pas ?). The seismic dataset was collected using the seismic acquisition system SEAL (Sercel, Ifremer) with a 24 trace and 600m streamer, and a $12.5 \mathrm{~m}$ hydrophone spacing. Bathymetric data were acquired with a Kongsberg EM122 multibeam system, processed using Ifremer CARAIBES ${ }^{\mathrm{TM}}$ v4.2 software and gridded into $30 \mathrm{~m}$ resolution DEMs (Digital Elevation Model; WGS84). Stratigraphic data are based on: (1) foraminifera biostratigraphy (zones and letter stages after BouDagher-Fadel, 2008, 2013, 2015; Table 1) and/or (2) strontium isotope stratigraphy (McArthur, 2012; see Courgeon et al., 2016 for details of analytical methods). Interpretation of volcanic rock samples is based on sample description and petrological analyses. Qualitative identification of crystalline phases was obtained from XRD data (BrukerD8 XRD instrument - Ifremer). Major element compositions of mineral phases were measured with a CAMECA SX100 electron microprobe at Laboratoire Magmas et Volcans (University of ClermontFerrand).

\section{Depositional and drowning history of the Sakalaves carbonate platform}

Three dredges have been carried out on top of the Sakalaves Platform (MOZ1-DW4, MOZ4-

DW01 and MOZ4-DR03; Fig. 2C) and one was realized on the western slope (MOZ1-DR13; Fig. 2A).

Eight distinct carbonate rock samples were collected (Table 1). Carbonate samples collected along the eastern flank of the carbonate platform (MOZ1-DR13-08) correspond to a Rupelian (Early

This article is protected by copyright. All rights reserved. 
Oligocene) skeletal packstone marked by a typical shallow-water carbonate assemblage (e.g. robust Larger Benthic Foraminifera - LBF) and by abundant volcanic fragments (Fig. $3 \mathrm{~A}$ ) that suggest the occurrence of exposed volcanic landforms at depositional time (Courgeon et al., 2016). These deposits suggest that colonization of volcanic morphology by shallow-water carbonate producers occurred during Early Oligocene time. Several Miocene carbonate samples have been recovered on top of the Sakalaves carbonate platform and are also characterized by various shallow-dwelling carbonate producers like LBF, corals and red algae (Table 1). Pliocene and Pleistocene outer platform deposits were collected on top of the Sakalaves drowned carbonate platform. These facies, which correspond mostly to micritic packstone bearing planktonic foraminifera (Fig. 3B,C), mark the end of shallow-water carbonate production and the drowning of the carbonate platform below the euphotic zone. MOZ4-DR3-C3 is typified by the direct contact between Miocene shallow-water carbonate deposits and Early Pliocene outer platform sediments (Fig. 3B) through an erosive unconformity that also reflects a Late Miocene-Early Pliocene drowning episode (Fig. 3D; see Godet et al., 2013 and references herein for details on drowning record in carbonate depositional sequences).

\section{Geophysical investigation of the Sakalaves Seamounts: evidence for Late Cenozoic extensional}

\section{tectonics and volcanism}

The Sakalaves Seamounts submarine relief as well as the nearby seafloor and superficial basinal sediments are cut by an extensive network of normal faults and fractures having an overall N170 trend (Fig. 2), parallel to the DR structure. The profile crossing the northern extremity of the

This article is protected by copyright. All rights reserved. 
study area (Fig. 4A) displays multiple normal faults that locally reach the seafloor to form welldeveloped and continuous escarpments that are up to $200 \mathrm{~m}$ high and tens of kilometres long (Fig. $2 A, B)$. The relatively flat submarine relief observed north of the Sakalaves Seamounts is also typified by numerous secondary faults and fractures (Fig. 2B). In addition, this domain is marked by seismicity characterized by extensional source mechanisms reflecting east-west extension (Fig. 2A,B; Ekström et al., 2012). Seismic profiles acquired across the Sakalaves drowned carbonate platform (Fig. 2C) highlight the contact between low-amplitude carbonate slope deposits and higheramplitude volcanic substratum along the seamount flanks (Fig. 5A). The top of the Oligo-Miocene Sakalaves carbonate platform is characterized by eroded volcanic morphologies and is cut by a dense network of fractures and normal faults delimitating distinct structural blocks (Fig. 2C). At the toe of the platform's western flank, the seafloor is especially marked by a sharp and straight $200 \mathrm{~m}$-high normal fault escarpment (Fig. 2C \& 5B). Our observations indicate extensional tectonic activity from the Neogene (potentially) and up to the present day along the Sakalaves Seamounts, i.e. during or, more likely, after the growth of the Sakalaves shallow-water carbonate platform (Fig. 3D).

In addition to normal fault escarpments, the seafloor south of the platform is characterized by groups of monogenetic cones with circular depressions at their apices (Fig. 2D), interpreted as volcanic constructional features. The seismic line carried out across these features shows chaotic and steep-slope volcanic edifices locally covered by well-stratified pelagic sediments. These volcanic edifices are also affected, locally, by normal faulting (Fig. 2D). The excellent morphological preservation of these volcanic cones, coupled with their shallow depths (300-500 m; locally above 
the top of the Oligo-Miocene Sakalaves Platform; Fig. 2D \& 4B), suggests that associated eruptions probably occurred during Late Cenozoic time.

\section{Petrographic and isotopic evidence for Late Cenozoic alkaline volcanism along the Sakalaves}

\section{Seamounts}

The volcanic nature of steep-slope and conical morphologic features observed on the seafloor and along seismic profiles (Fig. 2 \& 4B) has been confirmed by dredging operations, which led to the recovery of pyroclastic deposits, lavas and breccias belonging to strongly alkaline volcanism (Fig. 6).

Samples of volcanic rocks dredged on the western flank of the Sakalaves platform (MOZ1DR13; Fig. 2A) come from a breccia consisting of up-to-10cm blocks of altered lava (basanites and nephelinites; Fig. 6A) cemented by carbonates. These lavas display an aphyric to slightly porphyritic texture with varying proportions of $\mathrm{mm}$-sized altered olivine phenocrysts set in a clinopyroxenedominated microlitic to glassy groundmass that also contains nepheline, Fe-Ti oxides and apatite $( \pm$ plagioclase, amphibole, Cr-rich spinel). Pyroclastic material consisting of vesiculated lapilli and scoriaceous fragments strongly indurated with carbonate cement (MOZ1-DR14; Fig. 6D) was dredged from the slope of one of the well-preserved volcanic cones south of the Sakalaves Platform

(Fig. 2D and 4B). Stratification and sorting identified in some samples are symptomatic of tephra fallout deposits (Fig. 6D). These samples testify to the pyroclastic character of these cones and their probable construction in a subaerial environment. The modal composition of the lapilli is the same as for the DR13 samples. The dating of carbonate cements (Table 2) indicates that the associated 
eruptive activity occurred during Neogene to Pleistocene time, thus confirming our initial hypotheses based on morphological analysis. The rocks dredged from the southernmost Sakalaves Seamounts (MOZ1-DR15, Fig. 2D) show a compositional bimodality with nephelinites (similar to MOZ1-DR13) and phonolites. Phonolites contain phenocrysts of sanidine, nepheline, biotite, amphibole, aegirine and titanite, in an altered glassy mesostasis with microcrystals dominated by Kfeldspar, nepheline and Fe-Ti oxides (Fig. 6B). The sanidine crystals show complex zoning in many places involving successive resorption-crystallization processes that reflect physical and chemical changes of the melt from which crystals grew in magma reservoirs (Fig. 6C). All volcanic samples collected along the Sakalaves Seamounts are strongly altered and thus cannot be dated through radiometric methods.

\section{Discussion and Conclusions}

Normal fault escarpments observed along the Sakalaves Seamounts (Fig. 2) are overall parallel to the N170-trending DR structure (Fig. 1B) and appear similar to those reported farther north between the St Lazare and Paisley seamounts (see Franke et al., 2015). Our findings suggest a continuous Late Cenozoic diffuse east-west extension from the Lacerda Graben and the Paisley seamounts to the Sakalaves seamounts (Fig. 1B). This hypothesis is supported by the last decades' seismologic records, revealing significant seismic activity coupled with extensional earthquake source mechanisms (USGS, Ekström et al., 2012) along this segment of the DR (Fig. 1B). In parallel, the drowning of the Sakalaves shallow-water carbonate platform, which seemingly occurred during Late Miocene-Early Pliocene time (Fig. 3D), coincides with the onset and the acceleration of rifting-

This article is protected by copyright. All rights reserved. 
related extension and tectonic deformation that led to the formation and the development of the Kerimbas Graben at the northern extremity of the Mozambique Channel (Franke et al., 2015). These observations suggest that this drowning was potentially triggered by pulse(s) of rifting-related tectonic subsidence that outpaced carbonate accumulation potential.

In parallel, the late Cenozoic evolution of Sakalaves Seamounts was marked by strongly alkaline volcanism associated with the edification of volcanic cones, the deposition of layered pyroclastic deposits and effusive activity. While the lavas remain undated, the dating of carbonate cements including pyroclastic deposits indicates Neogene to Pleistocene (Table 2) eruptions. These chronostratigraphic results suggest that this volcanic activity was related to the Late Cenozoic development of the offshore EARS branch. Previous studies (Hernandez and Mougenot, 1988) have also highlighted EARS-related Neogene volcanism at the Kerimbas Graben. Moreover, silicaundersaturated alkaline rocks (e.g. olivine nephelinite, ankaratrites, titanite-bearing phonolite) are commonly described in the recent volcanism associated with the EARS (e.g. Rogers, 2006; Neukirchen et al., 2010; Fontijn et al., 2012) or Madagascar (e.g. Cucciniello et al., 2017). Feldspar + nepheline-phyric phonolites can be regarded as evolved products from basanitic to nephelinitic parental magmas. The observed bimodality of the samples (basanite-nephelinite and phonolite) is also a common feature of rift environments (Ivanov et al., 1998; Klaudius \& Keller, 2006). Our findings as well as recent results on the origin of magmatism in the Comoro Islands (Michon, 2016, see location in Fig. 1) demonstrate that the offshore EARS is not devoid of magmatism, in contrast with earlier conclusions (Franke et al., 2015). However, part of the volcanism observed on the Sakalaves Seamounts occurred prior to the Oligocene, as it seemingly partly constitutes the This article is protected by copyright. All rights reserved. 
substrate for shallow-dwelling carbonate producers (Fig. 3A), and can thus not be related to younger EARS development. Associated volcanic activity might have occurred during Cretaceous time as observed further north along the DR (Klimke and Franke, 2016; Sauter et al., 2018).

The timing, geometry and nature of the Late Cenozoic tectonic and volcanic activities reported along the Sakalaves Seamounts tend to confirm and extend previous hypotheses that suggest the southward development of the offshore EARS through the reactivation of the transpressional lithospheric fabric of the DR (e.g. Mc Gregor, 2015; Franke et al., 2015). As proposed by Franke et al., 2015, the Late Cenozoic extension observed along the Sakalaves Seamounts and the DR might be facilitated by a gravitational collapse of the underlying folded Mesozoic structure. The associated subsidence would thus be partly accommodated through isostatic adjustment mechanisms in response to the former Mesozoic compression phase. Late Cenozoic volcanism and extensional tectonics have also been reported in the southern central part of the Mozambique Channel in Bassas da India atoll and Europa Island realm (Fig. 1A; Courgeon et al., 2016; 2017). These observations tend to support the kinematic models (e.g. Chu and Gordon, 1999; Saria et al., 2014; Stamps et al., 2015) arguing that the EARS offshore branch extends farther south following the Quathlamba Seismic Axis (Fig. 1A). While this study provides new results to better assess the geometry of the EARS offshore branch, the most southern configuration of the Nubia-Somalia plate boundary and especially its junction with the Southwest Indian Ridge remains poorly documented.

This article is protected by copyright. All rights reserved. 


\section{Acknowledgements}

The authors are grateful to the Captain, Officers and crew members of the PTOLEMEE

(2014), PAMELA-MOZ1 (2014) and PAMELA-MOZ4 (2015) cruises onboard the R/Vs L'Atalante and

the Pourquoi pas? The oceanographic expeditions PTOLEMEE, PAMELA-MOZ1, PAMELA-MOZ4 and

SC's PhD were co-funded by TOTAL and IFREMER as part of the PAMELA scientific project. Finally,

the authors warmly thank the three anonymous reviewers for their insightful comments that greatly

improved the manuscript.

\section{References}

Bassias, Y., Leclaire L., 1990. The Davie Ridge in theMozambique Channel: Crystalline basement and intraplatemagmatism, NeuesJahrbuchfürGeologie und Paläontologie, 4, 67-90.

Bassias, Y., 1992. Petrological and geochemical investigation of rocks from the Davie Fracture Zone (Mozambique Channel) and some tectonic implications. Journal of African Earth Sciences 15, 321339.

BouDagher-Fadel, M.K., 2008.Evolution and Geological Significance of Larger Benthic Foraminifera.Developments in Palaeontology and Stratigraphy 21, 1-548.

BouDagher-Fadel, M.K., 2013.Diagnostic First and Last Occurrences of Mesozoic and Cenozoic Planktonic Foraminifera.Professional Papers Series, 1-4

BouDagher-Fadel, M.K., 2015.Biostratigraphic and Geological Significance of Planktonic Foraminifera, London, UCL Press, 298 p.

Calais, E., Ebinger, C., Hartnady, C., Nocquet, J. M., 2006. Kinematics of the East African Rift from GPS and earthquake slip vector data. Geological Society, London, Special Publications 259, 9-22.

Chu, D., Gordon, R.G., 1999. Evidence for motion between Nubia and Somalia along the Southwest Indian Ridge. Nature 398, 64.

Coffin, M. F., Rabinowitz, P. D., 1987. Reconstruction of Madagascar and Africa: evidence from the Davies Fracture Zone and Western Somali Basin. Journal of Geophysical Research 92, 9385-9406.

This article is protected by copyright. All rights reserved. 
Courgeon, S., Jorry, S.J., Camoin, G.F., BouDagher-Fadel, M.K., Jouet, G., Révillon, S., Bachèlery, P., Pelleter, E., Borgomano, J., Poli, E., Droxler, A.W., 2016. Growth and demise of Cenozoic isolated carbonate platforms: New insights from the Mozambique Channel seamounts (SW Indian Ocean). Marine Geology 380, 90-105.

Courgeon, S., Jorry, S.J., Jouet, G., Camoin, G.F., BouDagher-Fadel. Bachèlery, P., Caline, B., Boichard, R., Révillon, S., Thomas, Y.,Thereau, E., Guérin, C., 2017. Impact of Tectonic and volcanism on the Neogene evolution of isolated carbonate platforms (SW Indian Ocean). Sedimentary Geology 355. p. 114-131

Cucciniello, C.,Melluso, L., le Roex, A.P.,Jourdan, F.,Morra, V.,de Gennaro, R.Grifa, C., 2017. From olivine nephelinite, basanite and basalt to peralkalinetrachyphonolite and comendite in the Ankaratra volcanic complex, Madagascar: ${ }^{40} \mathrm{Ar} /{ }^{39} \mathrm{Ar}$ ages, phase compositions and bulkrockgeochemical and isotopic evolution. Lithos, 274-275, 363-382..

Dziewonski, A. M., T.-A. Chou and J. H. Woodhouse, 1981. Determination of earthquake source parameters from waveform data for studies of global and regional seismicity. Journal of Geophysical Research 86, 2825-2852.

Ekström, G., M. Nettles, and A. M. Dziewonski, The global CMT project 2004-2010: Centroid-moment tensors for 13,017 earthquakes, Phys. Earth Planet. Inter., 200-201, 1-9, 2012. doi:10.1016/j.pepi.2012.04.002

Fontijn, K., Williamson, D., Mbede, E., Ernst, G.G.J., 2012. The Rungwe Volcanic Province, Tanzania A volcanological review. Journal of African Earth Sciences 63, 12-31.

Franke, D., Jokat, W., Ladage, S., Stollhofen, H., Klimke, J., Lutz, R., Mahanjane, E.S., Ehrhardt, A., Schreckenberger, B., 2015. The offshore East African Rift System: Structural framework at the toe of a juvenile rift. Tectonics 34, 2086-2104.

Godet, A., 2013. Drowning unconformities: palaeoenvironmental significance and involvement of global processes. Sedimentary Geology 293, 45-66.

Grimison, N.L., Chen, W.P., 1988. Earthquakes in Davie Ridge-Madagascar region and the southern Nubian-Somalian plate boundary, Journal of Geophysical Research 93, 10,439-10,450.

Hartnady, C.J.H., 2002. Earthquake hazard in Africa: perspectives on the Nubia-Somalia boundary: news and view. South African journal of science 98, 425-428.

Hernandez, J., Mougenot, D., 1988: Pétrologie des laves alcalines du fossé sous-marin des Kerimbas. - P.I.C.G., 227: le magmatisme mésozoïque à actuel de la plaque Afrique et son contexte structural., Giens, France, 26-28 Sept. 1998; CIFEG, 15:114-117; Paris

Ivanov, A.V., Rasskazov, S.V., Boven, A., Andre, L., Maslovskaya, M.N., Temu, E.B.,1998. Late Cenozoic alkaline-ultrabasic ans alkaline basaltic magmatism of the Rungwe province, Tanzania.Petrology, 6, 3, 208-229.

Jorry, S., 2014. PTOLEMEE cruise, RV L'Atalante. http://dx.doi.org/10.17600/14000900

This article is protected by copyright. All rights reserved. 
Jouet, G., Deville, E., 2015. PAMELA-MOZ04 cruise, RV PourquoiPas ?. http://dx.doi.org/10.17600/15000700

Klaudius, J., Keller, J., 2006. Peralkaline silicate lavas at OldoinyoLengai, Tanzania.Lithos 91, 173-190.

Klimke, J., Franke, D., 2016. Gondwana breakup: no evidence for a Davie Fracture Zone offshore northern Mozambique, Tanzania and Kenya. Terra Nova 28, 233-244.

Klimke, J., Franke, D., Estevão, S.M., Leitchenkov, G., 2018. Tie points for Gondwana reconstructions from a structural interpretation of the Mozambique Basin, East Africa and the Riiser-Larsen Sea, Antarctica. Solid Earth 9, 25.

Leclaire, L., Bassias Y., Clocchiatti M.,Segoufin J., 1989. La Ride de Davie dans le Canal de Mozambique : approche stratigraphique et géodynamique. C.R. Acad. Sci.3, 08, II :1077-1082.

McArthur, J. M., Howarth,R. J. et al., 2012. Chapter 7 - Strontium Isotope Stratigraphy. The Geologic Time Scale 2012, Boston, Elsevier, 127-144.

McGregor, D., 2015. History of the development of the East African Rift System: A series of interpreted maps through time.Journal of African Earth Sciences 101, 232-252.

Michon, L., 2016. The volcanism of the Comoros Archipelago integrated at a regional Scale, in: Bachèlery, P., Lénat, J.-F., Di Muro, A., Michon, L. . (Eds.), Active volcanoes of the Soutwest Indian Ocean. Springer-Verlag, the Netherlands 333-344.

Miller, K.G., Kominz, M.A., Browning, J.V., Wright, J.D., Mountain, G.S., Katz, M.E., Sugarman, P.J., Cramer, B.S., Christie-Blick, N., Pekar, S.F., 2005.The phanerozoic record of global sea-level change.Science 310, 1293-1298.

Mougenot, D., Recq, M., Virlogeux, P., Lepvrier, C., 1986. Seaward extension of the East African rift. Nature321, 599-603.

Neukirchen, F., Finkenbein, T., Keller, J., 2010.The Lava sequence of the East African Rift escarpment in the OldoinyoLengai - Lake Natron sector, Tanzania. Journal of African Earth Sciences 58, 734-751

Olu, K, 2014. PAMELA-MOZ01 cruise, RV L'Atalante. http://dx.doi.org/10.17600/14001000

Rogers, N.W., 2006. Basaltic magmatism and the geodynamics of the East African Rift System., In Yirgu, G., Ebinger, C.J. \& Maguire, P.K.H. (eds) 2006. The Afar Volcanic Province within the East AfricanRift System. Geological Society, London, Special Publications, 259, 77-93.

Saria, E., Calais, E., Stamps, D. S., Delvaux, D., Hartnady, C. J. H., 2014. Present-day kinematics of the East African Rift. Journal of Geophysical Research. Solid Earth119, 3584-3600.

Sauter, D., Ringenbach, J. C., Cannat, M., Maurin, T., Manatschal, G., McDermott, K. G., 2018. Intraplate deformation of oceanic crust in the West Somali Basin; insights from long-offset reflection seismic data. Tectonics.

Stamps, D. S., laffaldano, G., Calais, E., 2015. Role of mantle flow in Nubia-Somalia plate divergence. Geophysical Research Letters 42, 290-296.

This article is protected by copyright. All rights reserved. 


\section{Captions}

Figure 1: (A) Modern East African Rift System outline. White lines correspond to major faults and fractures (from Chorowicz, 2005; Mc Gregor et al., 2015; Franke et al., 2015). The tectonic plates pattern is from Saria et al. (2004). Yellow dashed line corresponds to active seismic corridor: the Quathlamba Seismic Axis (QSA). Ba means Bassas da India and locates the Southern Mozambique isolated carbonate platforms, which are characterized by Late Cenozoic volcanism and extensional tectonic deformation (Courgeon et al., 2016; 2017). Sa means Sakalaves Seamounts and represents the study area. (B) Modern physiography of the northern Mozambique Channel. Red points correspond to records of earthquakes of magnitude $>4$ since 1950 (U.S. Geological Survey National Earthquake Information Center catalog). Earthquake source mechanisms come from the Harvard CMT catalog (Dziewonski et al., 1981; Ekström et al., 2012). Earthquake location accuracy is 20$30 \mathrm{~km}$. The graben and faulting (black dashed lines) designs are from Franke et al. (2015). Orange stars represent late Cenozoic volcanism of the Mozambique Channel (Hernandez and Mougenot, 1988, Michon, 2016, Courgeon et al, 2016, 2017).

Figure 2: Bathymetric maps (30m resolution) of the Sakalaves Seamounts. White lines correspond to the main normal faults and fractures observed on the seafloor. Dashes along faults indicate, when appropriate, the down-thrown compartments. Records of earthquakes of magnitude $>4$ since 1950 (U.S. Geological Survey National Earthquake Information Center catalog) are represented by red points. Earthquake source mechanisms come from the Harvard CMT catalog (Dziewonski et al., 1981; Ekström et al., 2010). Earthquake location accuracy is $20-30 \mathrm{~km}$. Red lines and lettering

This article is protected by copyright. All rights reserved. 
correspond to the locations of seismic profiles presented in figures $4 \& 5$. Yellow lines and stars indicate the locations of dredges. (A) General morphology of the Sakalaves Seamounts, black dashed squares locate close-ups presented in figure 2B,C,D. (B) Close-up of the northern part of the Sakalaves Seamount characterized by a complex normal fault network and modern seismicity. (C) Close-up of the Sakalaves drowned carbonate platforms. The black dashed square locates a close-up presented in figure 4B. (D) Close-up of the southern part of the Sakalaves Seamounts characterized by well-preserved conic volcanic morphologies in addition to normal fault escarpments.

Figure 3: (A) MOZ1-DR13-18: Oligocene (Rupelian) packstone bearing larger benthic foraminifera (LBF) and rhodoliths. This limestone includes large and abundant altered volcanic fragments. (B) MOZ4-DR3-C3: Erosive unconformity between a Miocene grainstone of LBF and red algae (RA) and an Early Pliocene packstone rich in planktonic foraminifera (PF). (C) MOZ4-DR3-C1: Pleistocene packstone with planktonic foraminifera. (D) Schematic and simplified Cenozoic evolution of the Sakalaves carbonate platform (see details in the text).

Figure 4: (A) Seismic profile PTO-SR099 (see location on Figure 2A,B). Red lines represent normal faults. (B) Seismic profile PTO-SR112 (see location on Figure 2D). Red lines correspond to normal faults.

Figure 5: The Sakalaves carbonate platform. (A) Seismic profiles PTO-SR108 and PTO-SR107 (see location in Figure 2C). Red lines represent normal faults. Green line corresponds to the contact between the carbonate platform deposits and the underlying substratum, possibly volcanic in origin.

The green dashed line corresponds to the tentative and simplified extrapolation of this contact at

This article is protected by copyright. All rights reserved. 
the seamount scale. The gray area represents the zone of seismic multiples. The yellow stars correspond to the projections of dredges along the seismic profiles. (B) Morphologic close-up of $200 \mathrm{~m}$-high fault escarpment observed on the eastern flank of the Sakalaves carbonate platform (see location in figure $2 \mathrm{C}$ ).

Figure 6: Photomicrographs (plane-polarized light), BSE image and photograph of volcanic samples from the Sakalaves seamounts: (A) nephelinite (MOZ1-DR13) with clinopyroxene microcrystals in a nepheline-bearing glassy groundmass; (B) phonolite (MOZ1-DR15) with abundant sanidine and nepheline phenocrysts in an altered glassy groundmass. (C) BSE image of zoned sanidine crystals from a MOZ1-DR15 phonolite; (D) volcanic breccia with vesiculated lapilli and ashes strongly indurated within carbonate cement (MOZ1-DR14).

This article is protected by copyright. All rights reserved. 
Table 1: Synthetic table of age and nature of carbonate samples collected along the Sakalaves

carbonate platform (see location of dredges in figures 2 \& 5). PF: Planktonic Foraminifera. LBF:

Larger Benthic Foraminifera. RA: Red Algae. Ech.: Echinoids.

\begin{tabular}{|c|c|c|c|c|}
\hline Sample & $\begin{array}{c}\text { Strontium } \\
\text { Isotope } \\
\text { Stratigraphy }\end{array}$ & $\begin{array}{c}\text { Foraminifera } \\
\text { Biostratigraphy }\end{array}$ & $\begin{array}{l}\text { Depositional } \\
\text { Environment }\end{array}$ & $\begin{array}{c}\text { Depositional } \\
\text { texture } \\
\text { Main components }\end{array}$ \\
\hline MOZ1-DW04-02b & $\begin{array}{l}1.02+/-0.04 \mathrm{Ma} \\
\text { Early Pleistocene }\end{array}$ & $\begin{array}{c}\text { N20-22a; } 3.8-1.0 \\
\text { Late Pliocene- } \\
\text { Early Pleistocene }\end{array}$ & Outer platform & $\begin{array}{l}\text { Packstone of PF } \\
\mathrm{PF} \text {, small benthic } \\
\text { foraminifera }\end{array}$ \\
\hline MOZ4-DW01-01b & $\begin{array}{c}1.12+/-0.04 \\
\text { Early Pleistocene }\end{array}$ & $\begin{array}{c}\text { N17b -22a; } 7.2-1.0 \\
\text { Late Miocene- } \\
\text { Early Pleistocene }\end{array}$ & Outer platform & $\begin{array}{l}\text { Wackestone of PF } \\
\text { PF, Gastropods }\end{array}$ \\
\hline MOZ4-DR3-C1 & $\begin{array}{l}1.39+/-0.05 \mathrm{Ma} \\
\text { Early Pleistocene }\end{array}$ & $\begin{array}{l}\text { N22a; } 1.8-1.0 \mathrm{Ma} \\
\text { Pleistocene }\end{array}$ & Outer platform & $\begin{array}{c}\text { Packstone of PF } \\
\text { PF, Gastropods, Ech. }\end{array}$ \\
\hline MOZ1-DW04-02a* & No data & $\begin{array}{c}\text { N19- N20; 5.3 - 3.4 } \\
\text { Ma } \\
\text { Zanclean } \\
\text { (Early Pliocene) }\end{array}$ & Outer platform & $\begin{array}{l}\text { Packstone of PF } \\
\text { PF, small benthic } \\
\text { foraminifera }\end{array}$ \\
\hline MOZ4-DW01-01c & $\begin{array}{l}6.33+/-0.06 \\
\text { Messinian } \\
\text { Miocene }\end{array}$ & No data & $\begin{array}{c}\text { Shallow-water } \\
\text { Carbonate platform }\end{array}$ & $\begin{array}{l}\text { Rudstone } \\
\text { Coral }\end{array}$ \\
\hline MOZ1-DW04-01* & $\begin{array}{c}8.80+/-0.35 \mathrm{Ma} \\
\text { Tortonian } \\
\text { Miocene }\end{array}$ & $\begin{array}{c}\text { N14- N21; 11.6-1.6 } \\
\text { Ma } \\
\text { Late Miocene- } \\
\text { Pleistocene }\end{array}$ & $\begin{array}{c}\text { Shallow-water } \\
\text { Carbonate platform }\end{array}$ & $\begin{array}{c}\text { Coralgal } \\
\text { Boundstone } \\
\text { Coral, RA }\end{array}$ \\
\hline MOZ4-DR3-C3 & No data & $\begin{array}{c}\text { Serravalian } \\
\text { (Middle Miocene) } \\
\text { N12-N13; 13.8-11.6 } \\
\text { Ma } \\
\text { reworked into } \\
\text { Zanclean (Early } \\
\text { Pliocene) } \\
\text { N19;5.3-3.8 Ma }\end{array}$ & $\begin{array}{c}\text { Shallow-water } \\
\text { Carbonate platform } \\
\text { reworked } \\
\text { into outer } \\
\text { platform }\end{array}$ & $\begin{array}{c}\text { Grainstone } \\
\text { LBF, RA, Halimeda } \\
\text { Reworked into } \\
\text { Packstone of PF } \\
\text { PF, Gastropods, Ech. }\end{array}$ \\
\hline MOZ1-DR13-08* & $\begin{array}{c}33.11+/-0.14 \mathrm{Ma} \\
\text { Rupelian } \\
\text { (Oligocene) }\end{array}$ & $\begin{array}{c}\text { P18- P19; 33.9-30.3 } \\
\text { Ma } \\
\text { Rupelian } \\
\text { (Oligocene) }\end{array}$ & $\begin{array}{c}\text { Shallow-water } \\
\text { Carbonate platform }\end{array}$ & $\begin{array}{c}\text { Packstone } \\
\text { LBF, RA, volcanic } \\
\text { fragments }\end{array}$ \\
\hline
\end{tabular}

This article is protected by copyright. All rights reserved. 
Table 2: Strontium isotope stratigraphy of MOZ1-DR14 carbonate cements.

\begin{tabular}{|c|c|}
\hline Sample & $\begin{array}{c}\text { Strontium Isotope } \\
\text { Stratigraphy }\end{array}$ \\
\hline MOZ1-DR14-02 & $\begin{array}{c}6.15+/ \text { - } 0.06 \mathrm{Ma} \\
\text { Messinian (Late Miocene) }\end{array}$ \\
\hline MOZ1-DR14-03a & $\begin{array}{c}4.60+/-0.22 \mathrm{Ma} \\
\text { Zanclean (Early Pliocene) }\end{array}$ \\
\hline MOZ1-DR14-03b & $3.28+/$ - 0.46 Ma \\
& Piancenzian (Late Pliocene) \\
\hline MOZ1-DR14-03c & $1.30+/-0.05 \mathrm{Ma}$ \\
& Pleistocene \\
\hline
\end{tabular}

This article is protected by copyright. All rights reserved. 

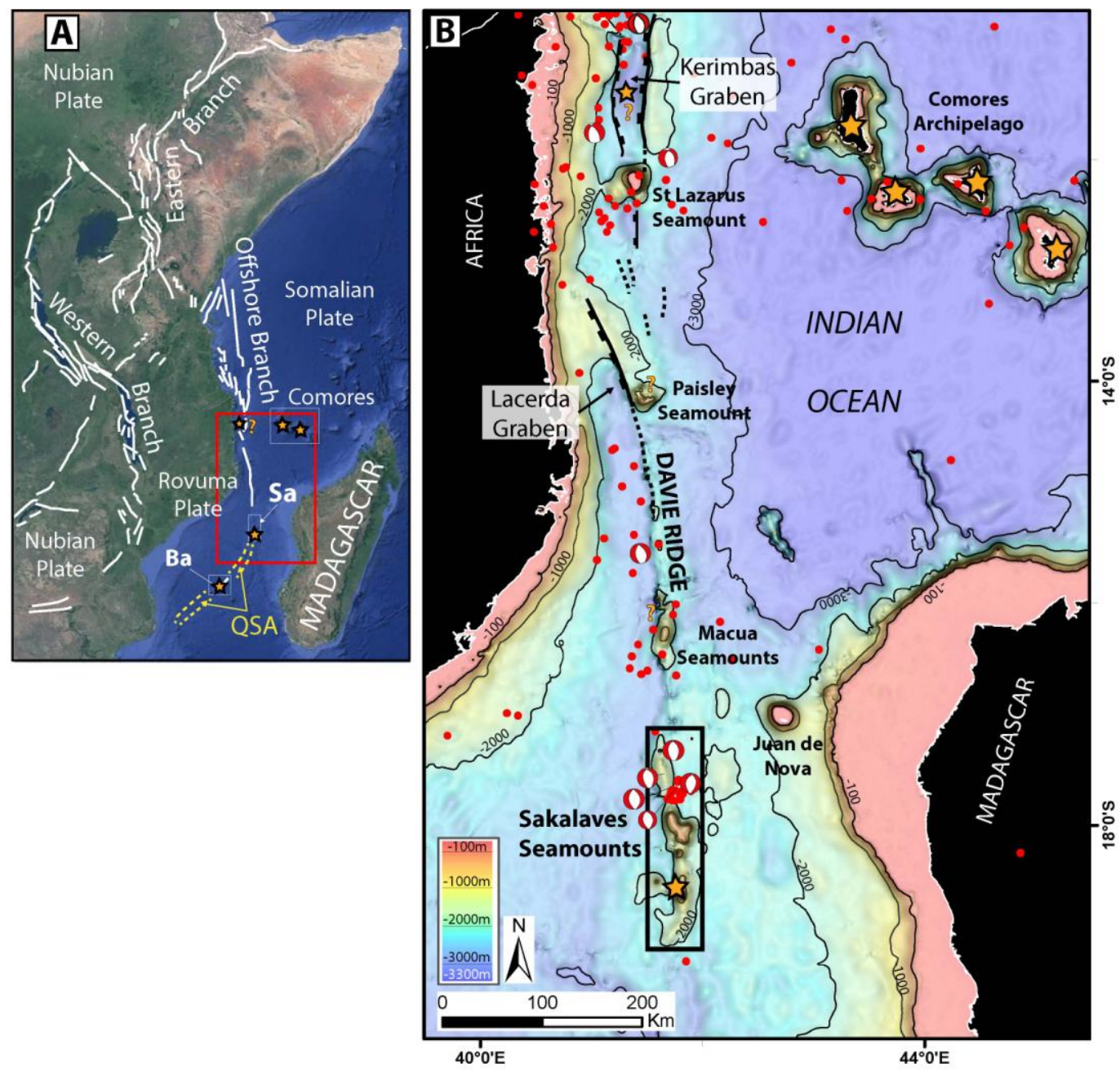

This article is protected by copyright. All rights reserved. 


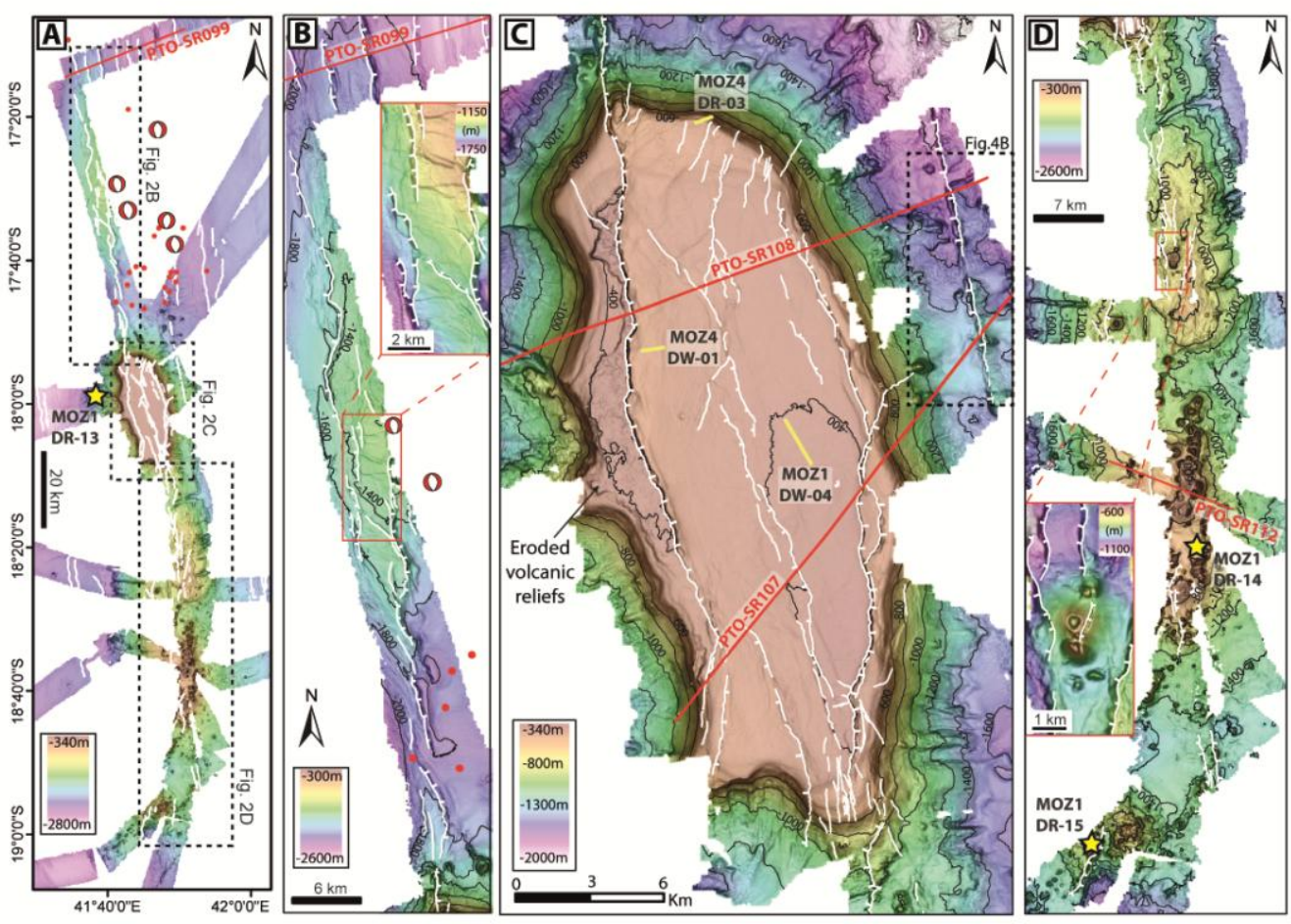

This article is protected by copyright. All rights reserved. 


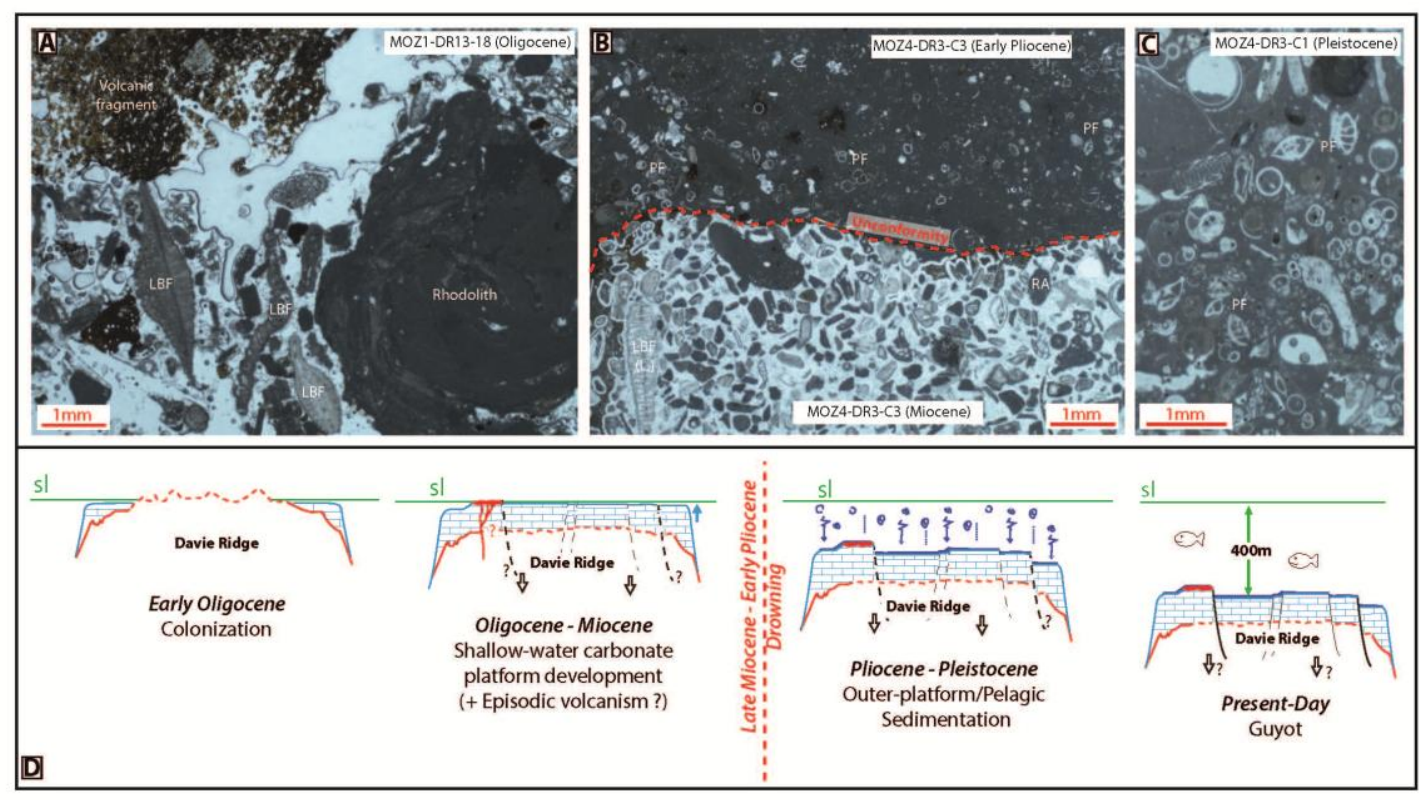

This article is protected by copyright. All rights reserved. 


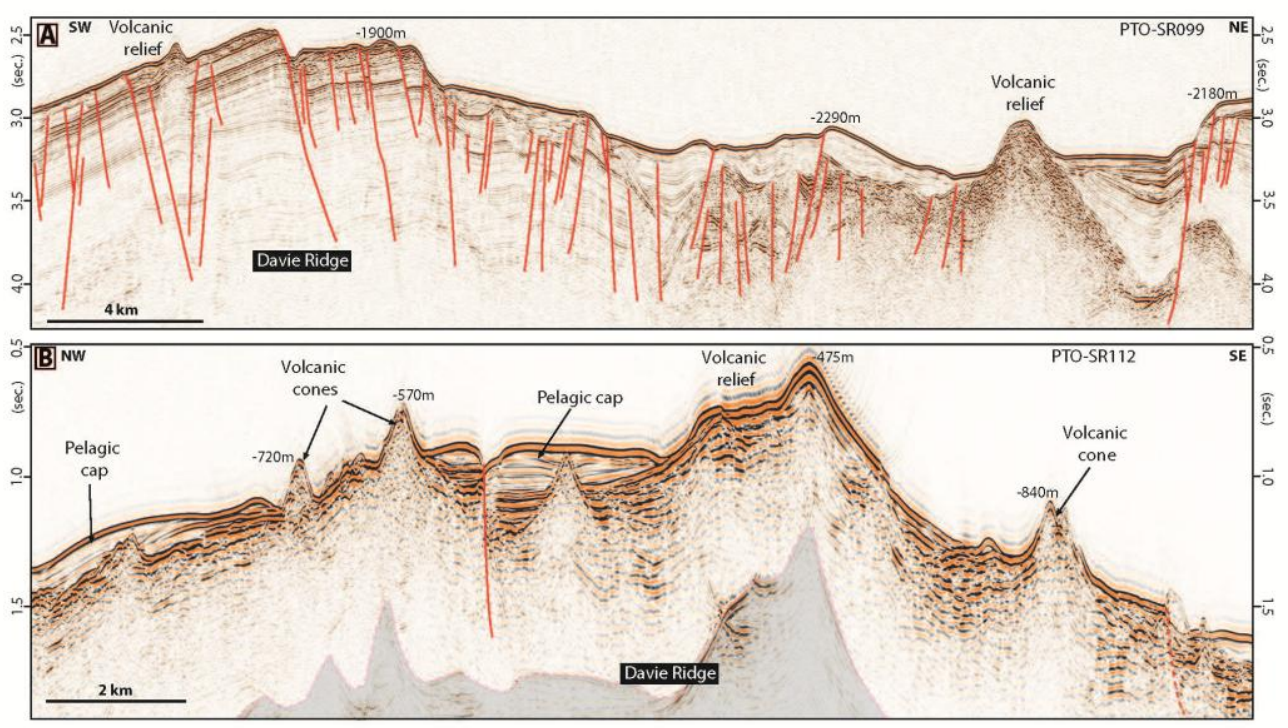

This article is protected by copyright. All rights reserved. 


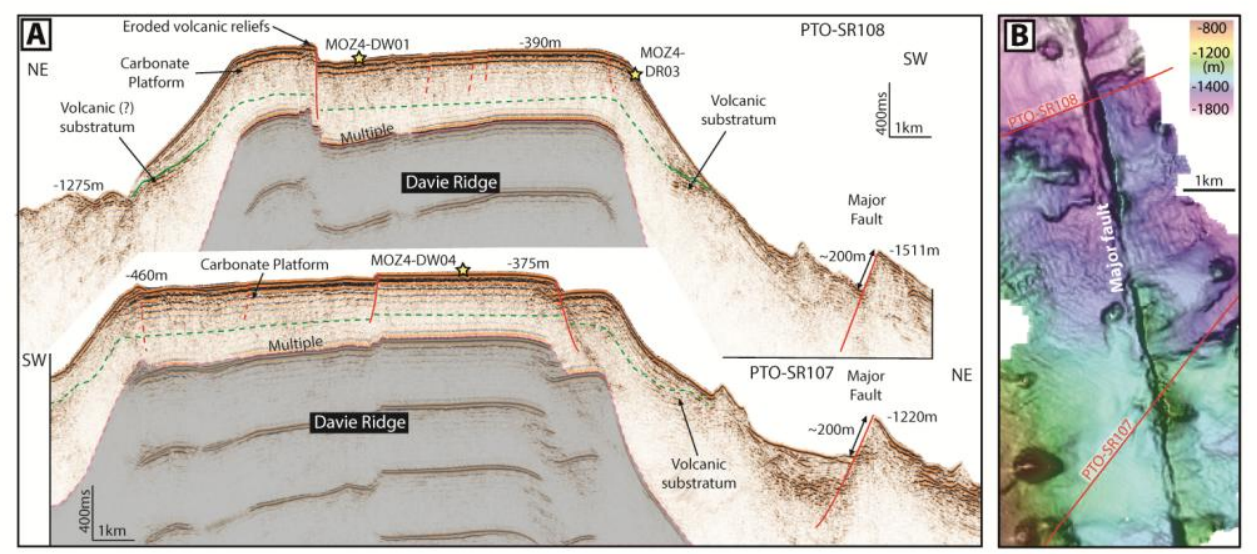

This article is protected by copyright. All rights reserved. 

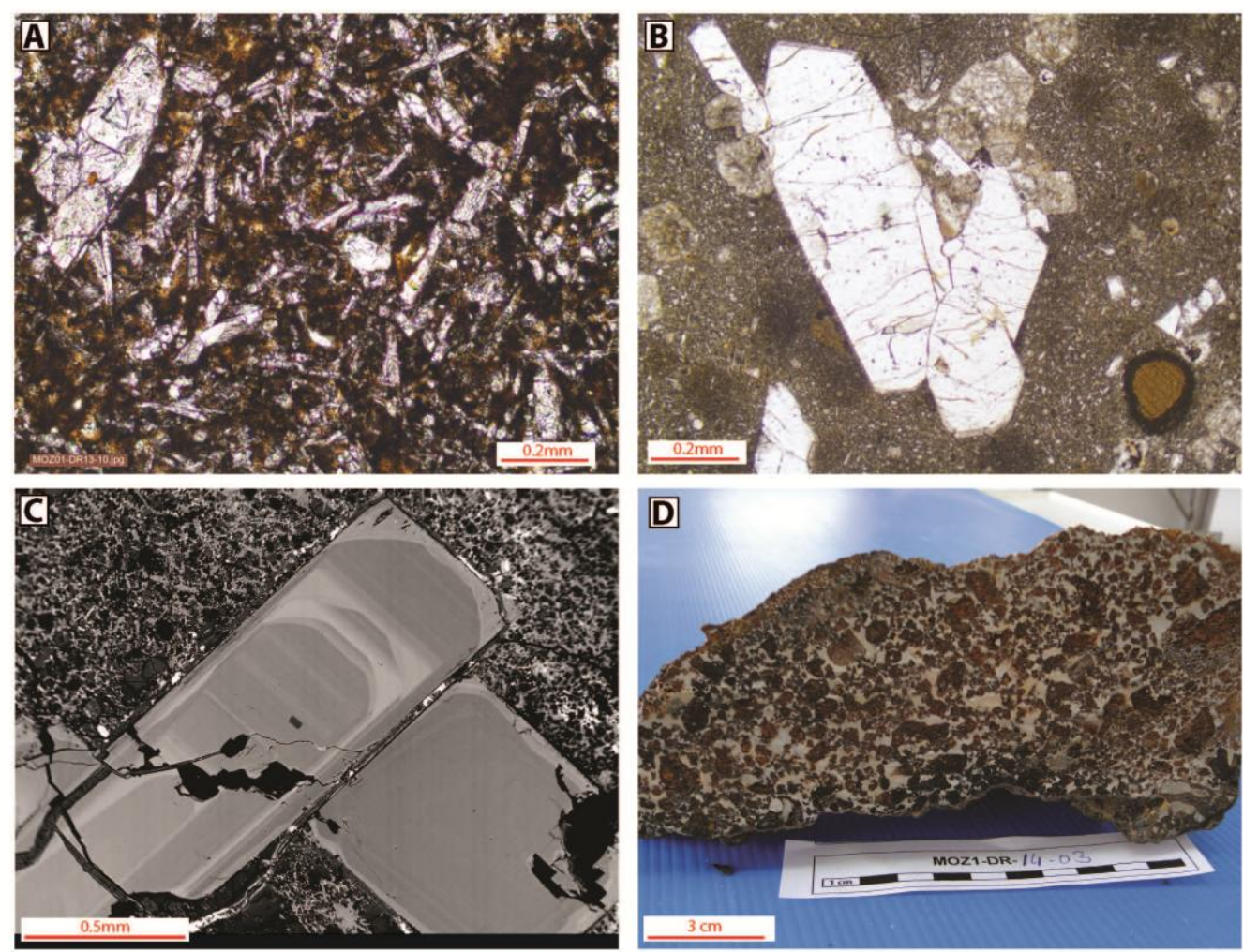

This article is protected by copyright. All rights reserved. 